\title{
Comparison of Backyard and Municipal Solid Waste Composting Phenomena by Physicochemical, FT-IR and X-Ray Diffraction Analysis
}

\author{
Manohara B* and Belagali Sl \\ Department of Studies in Environmental Science, University of Mysore, India
}

Submission: June 08, 2017; Published: July 27, 2017

*Corresponding author: Manohara B, Department of Studies in Environmental Science, University of Mysore, Manasagangothri, Mysore-570 006, Karnataka, India, Email: manu.bs25@gmail.com/slb_envsci@yahoo.com

\begin{abstract}
In the present work, comparison of characteristics of Backyard (Home) and Municipal Solid Waste (MSW) composting was studied by physico-chemical characteristics, Fourier Transform Infrared (FT-IR) spectroscopy and X-ray diffraction methods in order to determine the quality of the compost produced. Samples were analyzed for both the composting piles at 10,20,30, 40, 50 and 60 days of composting processes. Temperature of both the piles reached thermophilic phase before the $10^{\text {th }}$ day, but faster rate of decrease in temperature was observed for backyard composting. The concentrations of essential plant nutrients like Nitrogen, Phosphorous, Potassium, Calcium etc., were quite similar in both Backyard and MSW composting samples. The higher concentration of trace metals were observed in MSW compost samples, which can lead do accumulation of trace metals in agricultural lands and thereby enhancing the toxicity level. FT-IR spectra indicate the formation of stable aromatic structures from the long chain polysaccharides and other aliphatic compounds. Degradation of complex molecules into smaller constituents was indicated by X-ray Diffraction.
\end{abstract}

Keywords: Municipal solid waste composting; Backyard composting; Physico-chemical analysis; FT - IR; X-ray diffraction

\section{Introduction}

By the end of nineteenth century, Industrial development has shown a progressive trend in the world consumers. Presently not only the air but also earth itself becomes more and more polluted, especially with generation of solid waste in huge quantity [1]. Solid waste is the unwanted or useless solid material generated from combined residential, industrial and commercial activities of a given area. It may be categorized according to its origin (domestic, industrial, commercial, construction or institutional); according to its contents (organic material, glass, metal, plastic paper etc); or according to hazard potential (toxic, non-toxic, flammable, radioactive, infectious etc). Management of solid waste reduces or eliminates adverse impacts on the environment and human health and supports economic development and improved quality of life [2]. A number of processes are involved in effectively managing waste for a municipality. These include monitoring, collection, transport, processing, recycling and disposal. The important phase in the municipal solid waste management is 'Waste Processing/treatment and Disposal'. There have been several methods-traditional and modern-developed and evolved over time, e.g. composting, incineration, landfill, recycling, windrow composting, etc [3].
Composting can be regarded as the most usual method for recycling the organic fraction of municipal solid wastes (MSW), since it provides an agricultural amendment capable of mitigating the serious deficit of organic matter suffered by many agricultural soils, caused by the low use of organic materials in the fertilization programmes of crops. Among the different composting methods, the use of piles aerated by mechanical turning is noticeable because of the extent of its use. In these systems, size and shape of piles, as well as the frequency and way of turning, are very important, since they have a direct influence on the material aeration, a key factor in composting. Therefore, the peculiarities of the process implemented in each plant have a great influence on the final characteristics of the composts produced. Knowing the quality and quantity of compost is very important while applying it to the agricultural lands as a fertilizer. Improper supply of compost will lead to either accumulation of trace elements in soil leading to growth of soil toxicity or deficiency of essential nutrients [4].

The variation in nutrient concentration and structural changes during Backyard (Home) and Municipal Solid Waste (MSW) composting process can be evaluated through the analysis of different physico-chemical parameters and spectroscopic 
characterization. The aim of the present work is to determine the quality of the Municipal solid waste in comparison with Backyard composting through the determination of physicochemical parameters like $\mathrm{pH}$, temperature, EC, moisture content, etc., nutrient and trace metal concentrations, FT- IR spectroscopy, and X-ray Diffraction methods [5-10].

\section{Materials and Methods}

The study was carried out in two pilot plants of $3 \mathrm{ft} \times 3 \mathrm{ft} \times 3 \mathrm{ft}$ size, pile A (Municipal solid waste composting) and pile B (Backyard composting). Municipal solid waste samples were collected from Municipal solid waste composting site, Vidyaranyapuram, Mysore and dumped into pile A. In pile B, grass clippings, dry leaves, green leaves and kitchen wastes (containing vegetables, rice materials, paper cups, waste tea powder and egg shells) were taken. Moisture content was maintained around 40-60 \% for the growth of micro-organisms which leads to faster degradation. Both the piles were mixed periodically and samples were collected during 10, 20, 30, 40, 50 and $60^{\text {th }}$ day of composting process. Samples were first dried at $80^{\circ} \mathrm{C}$ in hot air oven, crushed well and sieved through $0.2 \mathrm{~mm}$ mesh. The powdered samples were then used for physicochemical and spectral characterization [11].

\section{Physicochemical parameters}

Temperature $\left({ }^{\circ} \mathrm{C}\right)$ of the composting piles was noted during the collection of samples. Moisture content (\%), Total soluble solids (mg/g) were estimated by gravimetric methods. $\mathrm{pH}$ and Electric conductivity were measured for the 1:5 compost-water suspension. Organic carbon (\%) and Organic matter (\%) were estimated using Walkey and Black method [12]. Water holding capacity (\%) was measured using filtration method. Chloride (\%) was determined by titration of compost: water (1:5) extract with Standard Silver nitrate solution, using potassium chromate as the indicator. Phosphorus (ppm) was determined through Vanadomolybdate method. Carbonates, Bicarbonates and Alkalinity $\left(\mathrm{mg} \mathrm{CaCO}_{3} / \mathrm{L}\right)$ were estimated by titration of compost: water (1:5) extract with standard $\mathrm{H}_{2} \mathrm{SO}_{4}$ solution using
Methyl orange and Phenolphthalein as indicators. Calcium and Magnesium were estimated by titration of compost: ammonium acetate (1:5) extract with standard EDTA solution using Eriochrome Black-T and Patton-Reeder's indicators. Brucine method was used for the estimation of Nitrate-Nitrogen, Sodium and Potassium were determined using Flame photometry. Humification Index was estimated through UV-Visible spectrophotometry [13].

For estimation of trace metals like lead, manganese, zinc, copper and iron etc, triacid (Nitric acid: Sulphuric acid: Perchloric acid in 9:2:1 ratio) extract of the compost sample was used for Atomic absorption spectrophotometer [14].

\section{Fourier transform infra-red (FTIR) spectroscopy and $\mathrm{X}$-ray diffraction method}

Different bonds ( $\mathrm{C}-\mathrm{C}, \mathrm{C}=\mathrm{C}, \mathrm{C}-\mathrm{O}, \mathrm{O}-\mathrm{H}$, etc.,) have different vibrational frequencies. These bonds present in the organic matter can be detected by identifying this characteristic frequency as an absorption band in the infrared spectrum. The dry composting samples were finely ground and $100 \mathrm{mg}$ of sample pressed to tablets with dry $1 \mathrm{mg} \mathrm{KBr}$ powder and analyzed through Shimadzu IR Prestige 21 FTIR Spectrophotometer. The overall structural changes during the decomposition can be studied using X-Ray Diffraction method. Samples were ground to fine powder and spectra were recorded on Bruker D8 Powder XRD Instrument using the source Copper K alpha [15-20].

\section{Results and Discussion}

Physico-chemical parameters and concentration of some essential plant nutrients in municipal solid waste and backyard composting samples are listed in Table 1 \& 2 respectively. Temperatures of both the piles increased at the beginning of the composting process indicating the decomposition of organic matter, and further decrease towards $60^{\text {th }}$ day of composting process indicates the stabilization of the decomposed organic matter. But the backyard compost attained maximum temperature $(54 \mathrm{oC})$ in $4-5$ days of composting process and then declined [21-23].

Table 1: Physico-chemical parameters of compost samples for pile A (MSW).

\begin{tabular}{|c|c|c|c|c|c|c|c|}
\hline S.No. & Sampling Days & $\mathbf{1 0}$ & $\mathbf{2 0}$ & $\mathbf{3 0}$ & $\mathbf{4 0}$ & $\mathbf{5 0}$ & $\mathbf{6 0}$ \\
\hline 1 & Temperature (oC) & 65 & 67 & 62 & 55 & 62 & 60 \\
\hline 2 & Moisture (\%) & 52 & 51 & 48 & 47 & 48 & 51 \\
\hline 3 & $\mathrm{pH}$ & 5.94 & 7.49 & 7.8 & 7.21 & 7.51 & 7.4 \\
\hline 4 & $\begin{array}{c}\text { Electric Conductivity } \\
\text { (dS/m) }\end{array}$ & 7.9 & 4.8 & 4.8 & 6.9 & 5.9 & 7.9 \\
\hline 5 & Calcium(meq/L) & 14.16 & 10.26 & 9.52 & 8.05 & 8.08 & 8.13 \\
\hline 6 & Magnesium (meq/L) & 9.51 & 4.75 & 4.14 & 4.46 & 5.89 & 2.06 \\
\hline 7 & Organic Carbon (\%) & 26.69 & 20.84 & 15.19 & 11.69 & 8.77 & 7.01 \\
\hline 8 & Organic matter (\%) & 46.01 & 35.93 & 26.19 & 20.15 & 15.12 & 12.09 \\
\hline 9 & TSS (mg/g) & 4.07 & 3.9 & 1.72 & 3.68 & 3.11 & 4.24 \\
\hline 10 & Chloride (\%) & 0.804 & 0.481 & 0.286 & 0.596 & 0.702 & 0.801 \\
\hline 11 & Carbonates (mg CaCO $/ \mathrm{L})$ & 0.0575 & 0.1724 & 0.0575 & 0.0568 & 0.1136 & 0.0568 \\
\hline
\end{tabular}




\section{Current Trends in Biomedical Engineering \& Biosciences}

\begin{tabular}{|c|c|c|c|c|c|c|c|}
\hline 12 & $\begin{array}{c}\text { Bicarbonates (mg } \\
\left.\mathrm{CaCO}_{3} / \mathrm{L}\right)\end{array}$ & 2.5278 & 1.2639 & 0.6319 & 1.0792 & 1.1928 & 2.4992 \\
\hline 13 & Alkalinity (mg CaCO3/L) & 2.6428 & 1.6087 & 0.7469 & 1.1928 & 1.42 & 2.613 \\
\hline 14 & $\begin{array}{c}\text { Water holding capacity } \\
(\%)\end{array}$ & 59.404 & 59.7 & 61.26 & 62.63 & 67 \\
\hline 15 & Available-Nitrogen (g/kg) & 0.831 & 0.878 & 0.836 & 0.714 & 0.719 & 0.702 \\
\hline 16 & Phosphorous (\%) & 2.35 & 2.04 & 2.03 & 1.89 & 1.9 & 1.31 \\
\hline 17 & Potassium (mg/g) & 19.8 & 18.3 & 16.7 & 11.1 & 9.5 & 8.8 \\
\hline 18 & Sodium (mg/g) & 7.5 & 7.1 & 6.9 & 4.5 & 2.7 & 2.3 \\
\hline 19 & Humification Index & 7.65 & 7.33 & 7.83 & 7.98 & 8.64 & 8.97 \\
\hline
\end{tabular}

Table 2: Physico-chemical parameters of compost samples from pile B (Home).

\begin{tabular}{|c|c|c|c|c|c|c|c|}
\hline S.No. & Sampling Days & 10 & 20 & 30 & 40 & 50 & 60 \\
\hline 1 & Temperature (oC) & 35 & 28 & 28 & 29 & 28 & 27 \\
\hline 2 & Moisture (\%) & 75 & 70 & 70 & 64 & 61 & 57 \\
\hline 3 & $\mathrm{pH}$ & 7.06 & 7.42 & 7.56 & 7.53 & 7.53 & 7.18 \\
\hline 4 & $\begin{array}{l}\text { Electric Conductivity } \\
(\mathrm{dS} / \mathrm{m})\end{array}$ & 5.8 & 5.2 & 3.3 & 4.3 & 3.6 & 3.5 \\
\hline 5 & Calcium(meq/L) & 17.27 & 18.62 & 17.51 & 17.07 & 17.29 & 12.54 \\
\hline 6 & Magnesium (meq/L) & 8.92 & 9.88 & 8.75 & 7.95 & 8.46 & 5.1 \\
\hline 7 & Organic Carbon (\%) & 27.27 & 22.59 & 29.8 & 28.63 & 23.96 & 20.06 \\
\hline 8 & Organic matter (\%) & 47.01 & 38.95 & 51.37 & 49.36 & 41.31 & 34.58 \\
\hline 9 & TSS (mg/gm) & 0.9 & 0.85 & 0.94 & 0.93 & 1.34 & 1.16 \\
\hline 10 & Chloride (\%) & 0.862 & 0.861 & 0.271 & 0.5 & 0.409 & 0.374 \\
\hline 11 & Carbonates $\left(\mathrm{mg} \mathrm{CaCO}_{3} / \mathrm{L}\right)$ & 0.2298 & 0.1724 & 0.1149 & 0.1149 & 0.1136 & 0.0568 \\
\hline 12 & Bicarbonates $\left(\mathrm{mg} \mathrm{CaCO}_{3} / \mathrm{L}\right)$ & 0.9192 & 1.3214 & 0.8043 & 0.4544 & 0.9088 & 0.9088 \\
\hline 13 & Alkalinity $\left(\mathrm{mg} \mathrm{CaCO}_{3} / \mathrm{L}\right)$ & 1.3788 & 1.6662 & 1.0341 & 0.6842 & 1.136 & 1.026 \\
\hline 14 & Water holding capacity (\%) & 61.94 & 48.74 & 68.94 & 73.89 & 72.19 & 67.99 \\
\hline 15 & Available Nitrogen $(\mathrm{g} / \mathrm{kg}$ ) & 1.826 & 1.739 & 1.664 & 1.628 & 1.556 & 1.53 \\
\hline 16 & Phosphorous (\%) & 0.98 & 0.83 & 0.77 & 0.44 & 0.41 & 0.39 \\
\hline 17 & Potassium (mg/g) & 2.1 & 1.8 & 1.6 & 1.3 & 1 & 0.8 \\
\hline 18 & Sodium $(\mathrm{mg} / \mathrm{g})$ & 1.2 & 0.9 & 0.7 & 0.7 & 0.6 & 0.4 \\
\hline 19 & Humification Index & 7.85 & 7.63 & 7.85 & 8.42 & 8.44 & 8.74 \\
\hline
\end{tabular}

Samples from both MSW and backyard composting processes were showed alkaline $\mathrm{pH}$, which was tending to neutral value towards the final stages of composting process. During different degradation stages, decrease in $\mathrm{pH}$ was observed, which can be attributed to the production of $\mathrm{CO}_{2}$ from organic acids and loss of nitrogen as reported by Lugtenberg (2009), and ammonia volatilization could be one of the most important reasons for pH drop (Kim et al., 2008) [10]. Decrease in the value of electrical conductivity towards later stages of the process was due to lowering of ionic concentration, indicating the growth in maturity of the compost.

The percentage of organic matter was similar in both MSW and backyard composting samples on $10^{\text {th }}$ day of composting process. But, towards the $60^{\text {th }}$ day of composting process the percentage of organic matter in MSW compost is much lesser than that of backyard compost. During composting, microorganisms break down organic matter in composting material into carbon dioxide, water, heat, and the final compost product. The decrease in organic matter is due to liberation of gases like carbon dioxide, methane, mercaptans etc. during the degradation process [24]. Total soluble solids were increased towards the later stages of composting process whereas water holding capacity was increased due to decomposition of larger constituents into small particles.

Sodium, phosphorous and potassium are the major essential macronutrients required for the growth of plants. From the Table $1 \& 2$, it is observed that, the concentration of essential plant nutrients is rich in municipal solid waste composting samples than that of backyard composting samples. On $60^{\text {th }}$ day of composting process phosphorous concentration was slightly higher $(1.31 \%)$ than the standard value $(0.4-1.1 \%)$ recommended by Ohai- EPA standards and Canadian Council of 
Ministers of the Environment (CCME) standards. The comparison of physicochemical parameters and essential plant nutrients concentration for $60^{\text {th }}$ composting samples of municipal and backyard composting is shown in (Figure $1 \mathrm{a} \& 1 \mathrm{~b}$ ).

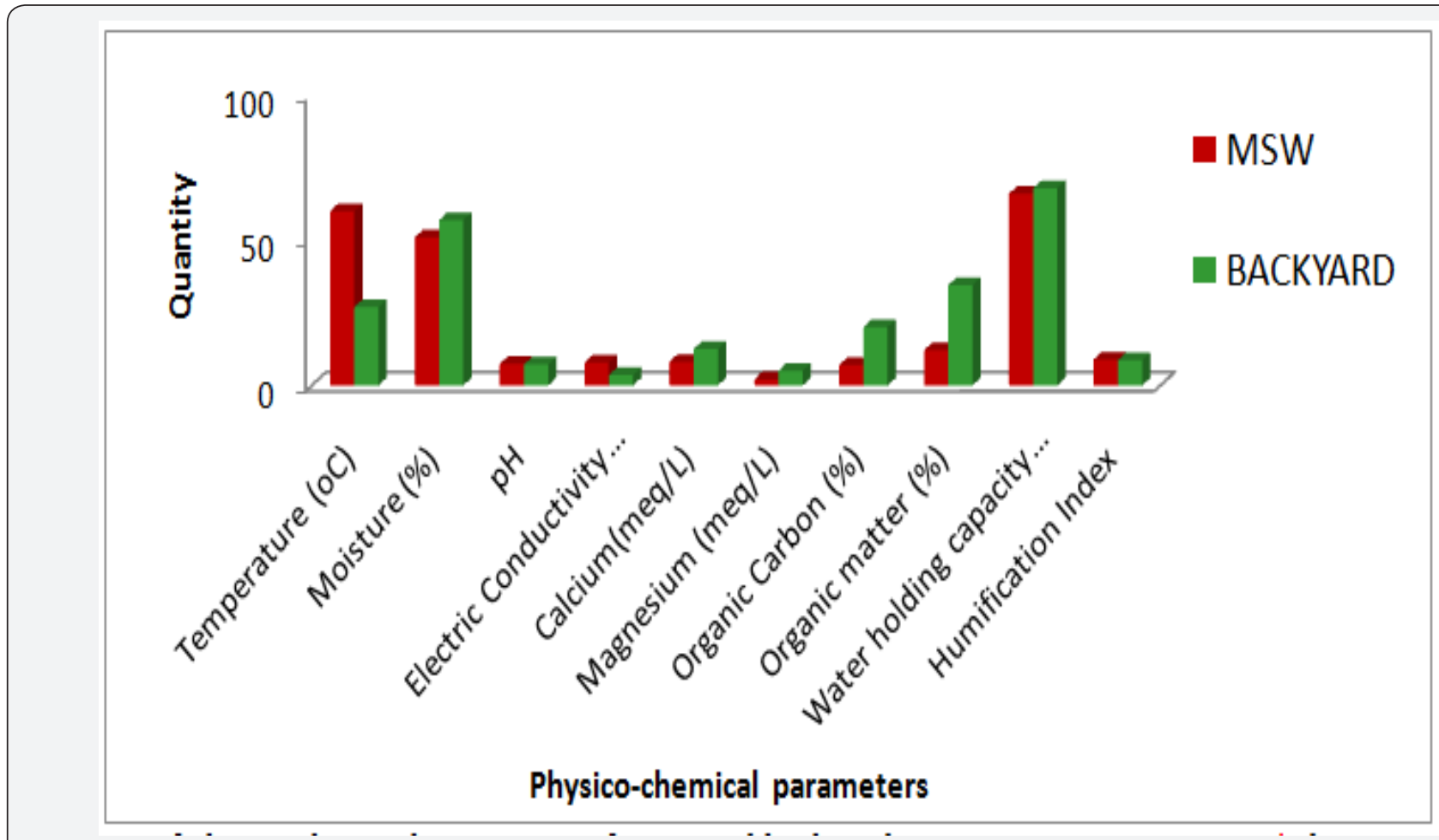

Figure 1a: Comparison of physicochemical properties of MSW and backyard composting process on $60^{\text {th }}$ day of composting process.

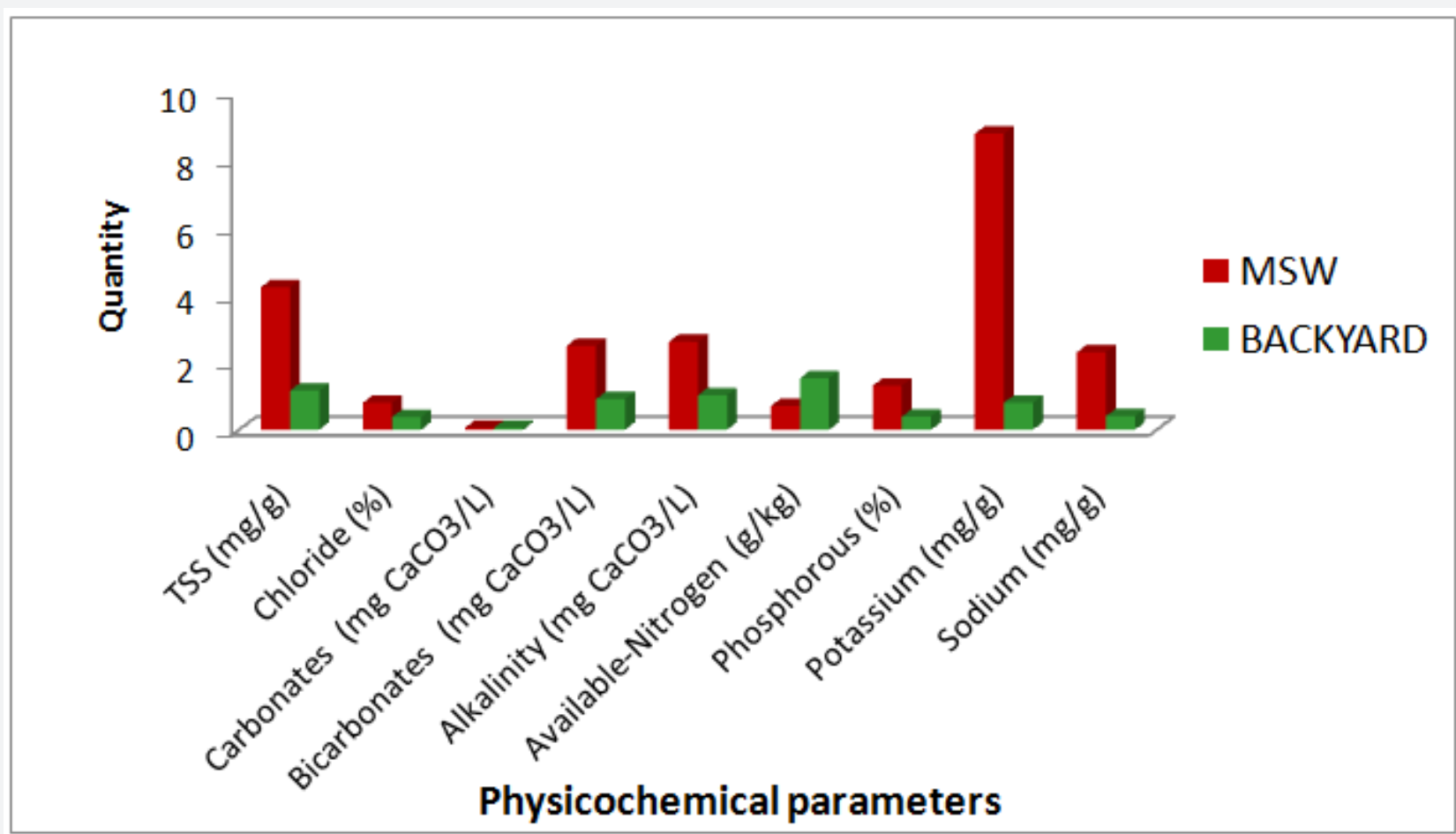

Figure 1b: Comparison of physicochemical properties of MSW and backyard compostingprocess on $60^{\text {th }}$ day of composting process. 


\section{Analysis of trace metals}

Trace metals are metals which are present extremely small quantities (less than 100ppm) in animal and plant cells and tissue [25]. The metals like Copper, Zinc, Iron, Manganese, Lead, Chromium, Nickel, etc are known as trace metals. Presence of these metals excess quantities is often toxic. Trace metals uptake by plants from the soil and successive accumulation in human tissues and biomagnifications through the food chain causes both human health and environment concerns. Hence it is very essential to know the concentration of these metals in compost before applying to agricultural lands, since the concentration of metal ions varies with the types and sources of compost. The trace metal concentrations for the composting samples from pile A (MSW) and pile B (backyard) are listed in Table $3 \& 4$ respectively.

Table 3: The trace metal concentrations for the composting samples from pile A (MSW).

\begin{tabular}{|c|c|c|c|c|c|c|c|c|}
\hline S.No. & $\begin{array}{c}\text { Sampling } \\
\text { Days }\end{array}$ & $\mathbf{1 0}$ & $\mathbf{2 0}$ & $\mathbf{3 0}$ & $\mathbf{4 0}$ & $\mathbf{5 0}$ & $\mathbf{6 0}$ & $\begin{array}{c}\text { Recommended } \\
\text { Standards }\end{array}$ \\
\hline 1 & $\begin{array}{c}\text { Copper } \\
(\mathrm{ppm})\end{array}$ & 412 & 384 & 375 & 376 & 365 & 330 & 1500 \\
\hline 2 & Zinc (ppm) & 263 & 271 & 249 & 237 & 227 & 201 & $700-1850$ \\
\hline 3 & Iron (g/kg) & 4.57 & 4.67 & 4.29 & 4.48 & 4.05 & 3.92 & NA \\
\hline 4 & $\begin{array}{c}\text { Manganese } \\
((\mathrm{ppm})\end{array}$ & 377 & 372 & 337 & 290 & 293 & 260 & $5-200$ \\
\hline 5 & Lead (ppm) & 281 & 276 & 276 & 257 & 255 & 241 & $150-500$ \\
\hline 6 & $\begin{array}{c}\text { Chromium } \\
(\mathrm{ppm})\end{array}$ & 179 & 182 & 168 & 169 & 163 & 159 & 210 \\
\hline 7 & Nickel (ppm) & 37 & 32 & 29 & 24 & 25 & 22 & $62-180$ \\
\hline
\end{tabular}

Table 4: The trace metal concentrations for the composting samples from pile B (Home).

\begin{tabular}{|c|c|c|c|c|c|c|c|c|}
\hline S.No. & $\begin{array}{c}\text { Sampling } \\
\text { Days }\end{array}$ & $\mathbf{1 0}$ & $\mathbf{2 0}$ & $\mathbf{3 0}$ & $\mathbf{4 0}$ & $\mathbf{5 0}$ & $\mathbf{6 0}$ & $\begin{array}{c}\text { Recommended } \\
\text { Standards }\end{array}$ \\
\hline 1 & $\begin{array}{c}\text { Copper } \\
\text { (ppm) }\end{array}$ & 247 & 242 & 236 & 235 & 212 & 201 & 1500 \\
\hline 2 & Zinc (ppm) & 142 & 141 & 138 & 139 & 128 & 115 & $700-1850$ \\
\hline 3 & Iron (g/kg) & 2.714 & 2.683 & 2.655 & 2.55 & 2.162 & 2.012 & NA \\
\hline 4 & $\begin{array}{c}\text { Manganese } \\
((\mathrm{ppm})\end{array}$ & 94 & 82 & 87 & 81 & 70 & 66 & $5-200$ \\
\hline 5 & Lead (ppm) & 35 & 36 & 33 & 27 & 26 & 26 & $150-500$ \\
\hline 6 & $\begin{array}{c}\text { Chromium } \\
(\mathrm{ppm})\end{array}$ & 32 & 34 & 30 & 28 & 24 & 23 & 210 \\
\hline 7 & Nickel (ppm) & 28 & 27 & 21 & 22 & 20 & 17 & $62-180$ \\
\hline
\end{tabular}

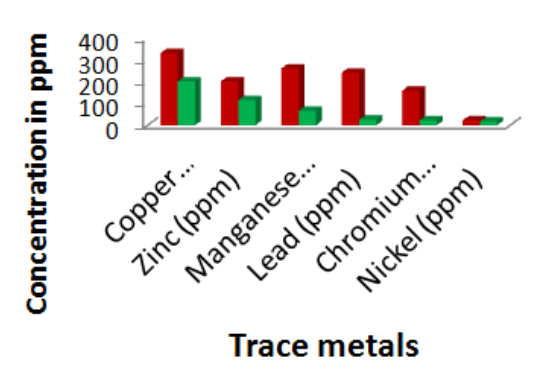

Figure 1c: Trace metals.

From the obtained data, on $60^{\text {th }}$ day of composting process, in both the municipal solid waste and backyard composting samples trace metal concentrations were under permissible limits (except manganese for MSW) of. Ohai- EPA standards and Canadian Council of Ministers of the Environment (CCME) standards Reduction of heavy metal concentrations resulted at the later stages of composting. On average, the trace metal concentrations in the composting samples were found in the following orders: iron >copper >manganese >zinc >lead $>$ chromium >nickel for MSW composting and for backyard composting: iron >copper $>$ zinc $>$ manganese $>$ lead $>$ chromium $>$ nickel (Figure 1c).

\section{Fourier transform infra-red (FT IR) spectroscopy}

Figure 1a shows the FT IR spectra of composting samples from piles A and B at different maturity stages. B1, B2, B3, B4, B5 and $B 6$ represent the spectra of $10^{\text {th }}, 20^{\text {th }}, 30^{\text {th }}, 40^{\text {th }}, 50^{\text {th }}$ and $60^{\text {th }}$ days old samples respectively, for pile A. Similarly M1, M2, M3, M4, M5 and M6 represent the spectra of $10^{\text {th }}, 20^{\text {th }}, 30^{\text {th }}, 40^{\text {th }}, 50^{\text {th }}$ and $60^{\text {th }}$ day's old samples of pile B.

A broad absorbance band was observed around 3300-3400 $\mathrm{cm}^{-1}$ (H-bonds, - $\mathrm{OH}$ groups) and it much broadened towards 60th day. Two distinct peaks were observed at 2850, $2950 \mathrm{~cm}^{-1}$ (C-H 
asymmetric, $\mathrm{C}-\mathrm{H}$ stretching for $-\mathrm{CH}$ group). Sharp absorption bands were observed at $1650 \mathrm{~cm}^{-1}(\mathrm{C}=\mathrm{Cstr}$ in aromatic region or C-Ostr), $1560 \mathrm{~cm}^{-1}$ (amide bonds) and $1450 \mathrm{~cm}^{-1}$ (C-Hdef for $\mathrm{CH} 2$ and $\mathrm{CH} 3$ groups). Broad peak at $1040-1080 \mathrm{~cm}^{-1}$ region represents C-Ostr of polysaccharides. Sharp absorption band appeared at $400 \mathrm{~cm}^{-1}$, which is due to the stretching vibrations of Si-O-Si or O-Si-O bonds (Jenn-Hung Hsu et al., 1998).

\section{X-ray diffraction analysis}

X-ray diffraction spectra of composting samples from MSW and backyard composting at different maturity stages are shown in (Figure 1d), in which B1, B2, B3, B4, B5 and B6 represent the spectra of $10^{\text {th }}$ to $60^{\text {th }}$ day's samples respectively, for pile $A$. Similarly M1, M2, M3, M4, M5 and M6 represent the spectra of $10^{\text {th }}$ to $60^{\text {th }}$ day's samples of pile B.
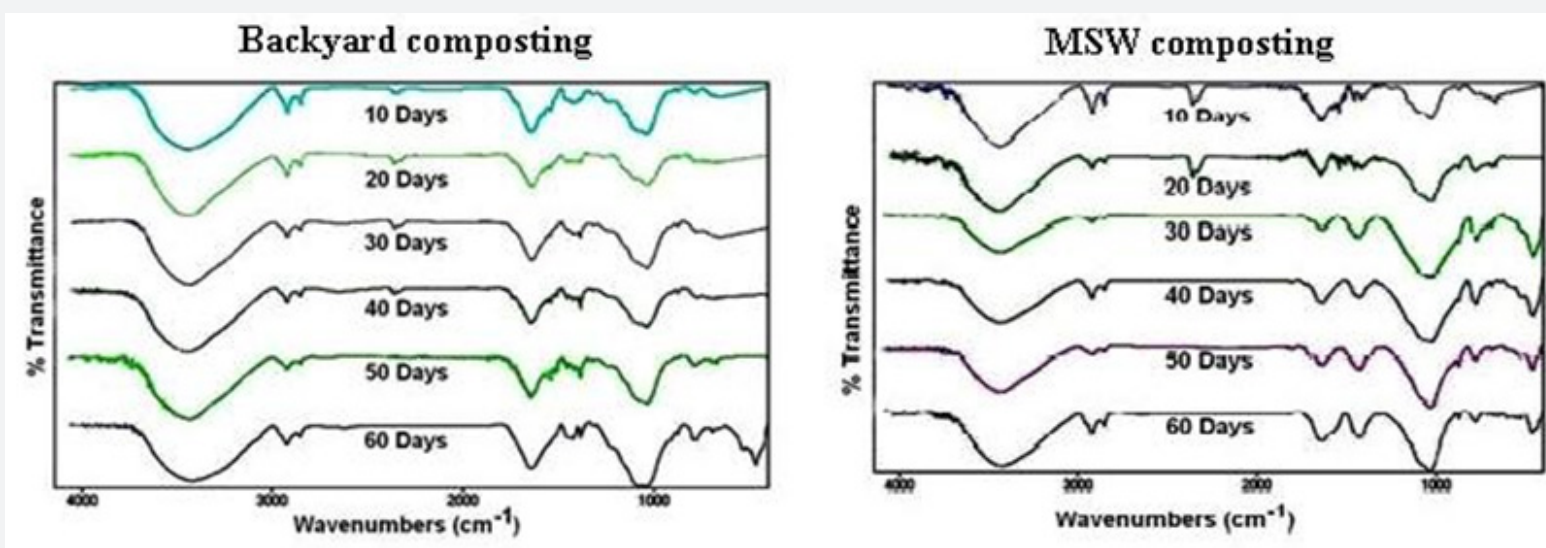

Figure 1d: FT IR spectra of composting samples at different maturity stages for pile A and B.

When there is periodic arrangement of atoms the X-rays will be scattered only in certain directions when they hit the formed lattice planes (formed by atoms). This will cause high intensity peaks (the width of the peaks depends on other variables). Amorphous phase: X-rays will be scattered in many directions leading to a large bump distributed in a wide range (2 Theta) instead of high intensity narrower peaks.From the (Figure 1e), it is observed that the number of intense peaks which are present in spectra of the 10th day sample was reduced towards the $60^{\text {th }}$ day of composting process whereas less intense peaks increased towards later stages of composting process, which indicates the conversion of solid wastes from crystalline to amorphous phase during the degradation process.
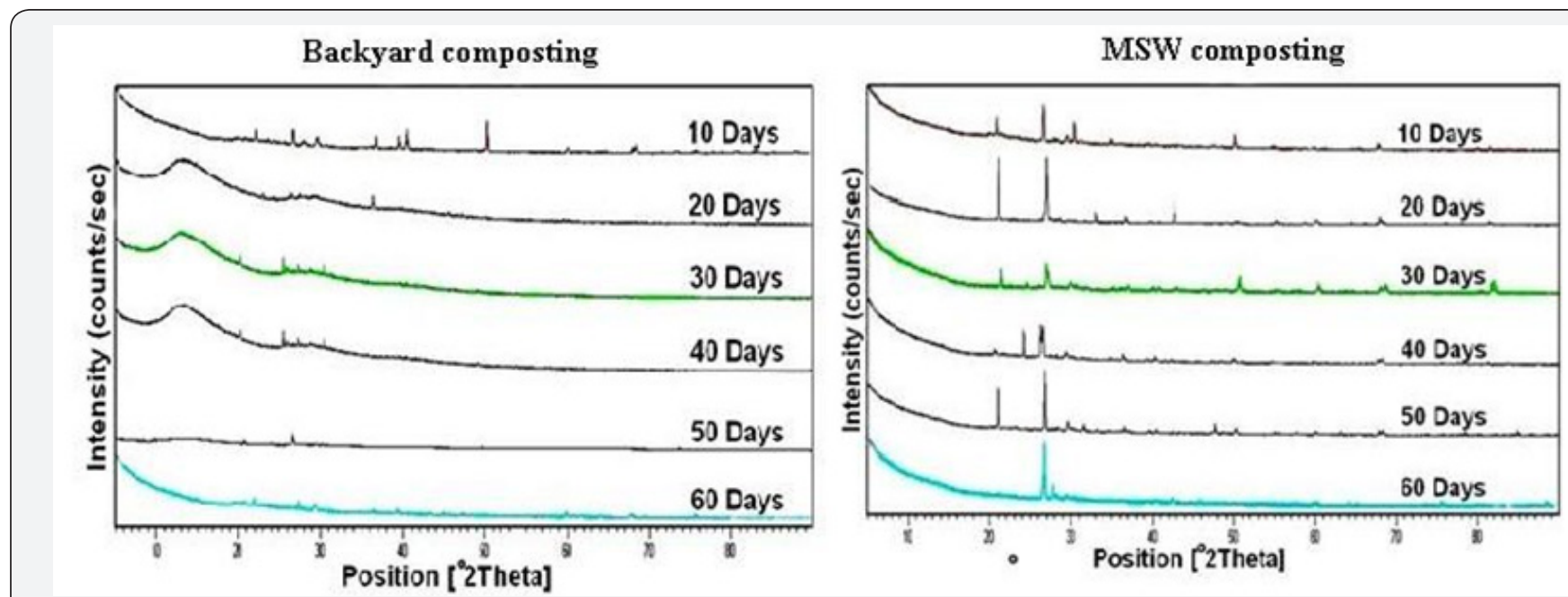

Figure 1e:XRD spectra of composting samples at different maturity stages for piles $A$ and $B$.

\section{Conclusion}

From the observations, compost prepared from municipal solid waste is a rich source of essential plant nutrients compare to that of backyard (Home) composting. And also, the concentrations of trace elements like lead, chromium, Nickel, etc., were also higher in municipal solid waste. The metal ion concentrations were within the permissible limits, since, the number of industries was lesser in Mysore city compare other cities and this compost can used as good fertilizer. The concentration of nutrients and trace metals in compost varies with the different composting methods and sources of solid waste. Hence, proper guidance should give to the farmers 
during its use as a fertilizer, to avoid the soil and ground water pollution. The loss of essential nutrients with the release of leachate from the pile during the composting process is needed to be minimized. It will also help to prevent the soil and ground water pollution in that area.

\section{References}

1. Rajput R, Prasad G and Chopra AK (2009) Scenario of solid waste management in present Indian context. Caspian Journal of Environmental Science 7(1): 45-53.

2. Barker AV (1997) Composition and uses of compost, agricultural uses of by-products and wastes, ASC Symposium series. American Chemical Society 668(10): 140-162.

3. Bermal MP, Paredes C, Sánchez Monedero MA and Cegarra J (1998) Maturity and stability parameters of composts prepared with a wide range of organic wastes. Bioresource Technology 63(1): 91-99.

4. Boni MR and Musmeci L (1998) Organic fraction of municipal solid waste (OFMSW): extent of biodegradation. Waste Management \& Research 16(2): 103-107.

5. Bord na Mona (2003) Compost testing and analysis Serviceinterpretation of results, available from Bord na Mona, Newbridge, Co. Kildare.

6. Brinton WF (2003) Interpretation of Waste and Compost Tests, Journal of the Woods End Research Laboratory 1(4): 1-6.

7. Campell AG, Folk RL and Tripepi RR (1997) Wood ash as an amendment in municipal sludge and yard composting processes. Compost Science \& Utilization 5(1) 62-73.

8. Castaldi P, Alberti G, Merella R and Melis P (2005) Study of the organic matter evolution during municipal solid waste composting aimed at identifying suitable parameters for the evaluation of compost maturity. International Workshop " Hydro-Physico-Mechanics of Landfills" LIRIGM, Grenoble 1 University France 25(2): 209.

9. Chen TQ Huang D, Gao Z, Huang Y, Zheng and Li Y (2002) Temperature dynamic during the sewage sludge composting process. Acta Ecologica Sinica 22(1): 736-741.

10. Elango D, Thinakaran N, Panneerselvam P and Sivanesan S (2009) Thermophilic composting of municipal solid waste. Applied Energy 86(5): 663-668.

11. Farid Barjea, Loubna El Felsa, Houda El Hajjoujia, Soumia Amirb and Peter Wintertonc, et al. (2012) Molecular behaviour of humic acidlike substances during co-composting of olive mill waste and the organic part of municipal solid waste. International Biodeterioration \& Biodegradation 74: 17-23.
12. Gallardo Lara F and Nogales R (1987) Effect of application of town refuse compost on the soil-plant system-a review. Biological Wastes 19(1): 35-62.

13. Giovanni Gigliotti, Klaus Kaiser, Georg Guggenberger and Ludwig Haumaie (2002) Differences in the chemical composition of dissolved organic matter from waste material of different sources. Biology and Fertility of Soils 36(5): 321-329.

14. Gray KR, Sherman K and Biddlestone AJ (1971) A review of composting. Part 1 Microbiology and bio-chemistry. Process Biochemistry 6(6): 3236.

15. Hogarh JN, Fobil JN, Ofosu Budu GK, Carboo D and Ankrah NA et al (2008) Assessment of Heavy Metal Contamination and Macro-Nutrient content of Composts for Environmental Pollution Control in Ghana. Global Journal of Environmental Research 2(3): 133-139.

16. Huang GF, Wu QT, Wong JWC and Nagar BB (2006) Transformation of organic matter during co-composting of pig manure with sawdust. Bioresour Technol 97(15): 1834-1842.

17. Janakiram $\mathrm{T}$ and Sridevi $\mathrm{K}$ (2010) Conversion of waste into wealth: A study in solid waste management. Advances in Management 7(4): 1340-1345.

18. Jayarama Reddy P (2011) Municipal solid waste management: Processing-Energy Recovery-Global Examples 1: 27.

19. Jenn Hung Hsu and Shang Lien Lo (1999) Chemical and spectroscopic analysis of organic matter transformations during composting of pig manure. Environmental Pollution 104(2): 189-196.

20. Lucimar LF, Wilson TL da Silvaa, Débora MBP Miloria, Simõesa ML and Martin Neto L (2010) Characterization of organic matter from composting of different residues by physicochemical and spectroscopic methods. Bioresour Technol 101(6): 1927-1934.

21. Mahdi A, Azni I and Syed Omar SR (2007) Physicochemical characterization of compost of the industrial tannery sludge. Journal of Engineering Science and Technology 2(1): 81-94.

22. Mani AK, Santhi R and Sellamuthu KM (2007) A handbook of laboratory analysis, 1st edition, A.E. Publications No.10. Sundaram, P.N. Pudur, Coimbatore, India 8(2): 156-167.

23. Marugg C, Gerbus M, Hansen RC, Keener HM and Hoitink HAJ (1993) A kinetic model of the yard waste composting process. Compost Science \& Utilization 1(1): 38-51.

24. Saha and Arun Kumar (2008) Methods of Physical and Chemical Analysis of Soil, (1 $1^{\text {st }}$ edn). ISBN 8127242084, India.

25. Sharma AK and Gupta DP (2006) Physico-chemical characteristics of municipal solid waste of Bhopal city. Enviromedia 25(4): 871.

- Quality Editorial service

- Swift Peer Review

- Reprints availability

- E-prints Service

- Manuscript Podcast for convenient understanding

- Global attainment for your research

- Manuscript accessibility in different formats

( Pdf, E-pub, Full Text, Audio)

- Unceasing customer service

Track the below URL for one-step submission https://juniperpublishers.com/online-submission.php 